\title{
Assessment of the antioxidant effect of astaxanthin in fresh, frozen and cooked lamb patties
}

\author{
D.E. Carballo ${ }^{\text {a }}$ I. Caro ${ }^{\text {b }}$, S. Andrés ${ }^{\text {, F.J. Giráldez }}{ }^{\mathrm{c}}$, J. Mateo $^{\mathrm{a} *}$ \\ ${ }^{a}$ Department of Food Hygiene and Technology, Faculty of Veterinary Sciences, Universidad de León, Campus de \\ Vegazana, s/n 24071, León, Spain \\ ${ }^{b}$ Department of Food Science and Nutrition, College of Medicine, University of Valladolid, 47005 Valladolid, Spain \\ `Instituto de Ganadería de Montaña (CSIC-Universidad de León), Finca Marzanas, E-24346 Grulleros, León, Spain
}

*Corresponding author. Tel.: +34 987291247
E-mail address: jmato@unileon.es (Javier Mateo)

\begin{abstract}
Astaxanthin is a natural red carotene exerting a strong antioxidant action. The effect of this carotene on the oxidative stability of raw and cooked lamb patties was evaluated. Seven experimental treatments were included in this study depending on the antioxidants added, which are: no antioxidant added (control), $450 \mathrm{mg} / \mathrm{kg}$ of sodium metabisulphite, $500 \mathrm{mg} / \mathrm{kg}$ of sodium ascorbate, and $20 \mathrm{mg} / \mathrm{kg}, 40 \mathrm{mg} / \mathrm{kg}, 60 \mathrm{mg} / \mathrm{kg}$ and $80 \mathrm{mg} / \mathrm{kg}$ of astaxanthin. The raw patties were either refrigerated for up to 11 days or frozen for 3 months under aerobic conditions. Changes in thiobarbituric reactive substances (TBARS), instrumental colour, $\mathrm{pH}$ and Eh were determined in the refrigerated patties and TBARS in the frozen patties. Volatile compounds were determined in cooked patties and cholesterol oxides in both cooked and after cooking microwave reheated patties. The changes in TBARS of cooked patties during a four-day refrigerated storage were also
\end{abstract}


studied. Compared to the control patties, the use of astaxanthin reduced the TBARS generation in a manner depending on the dose for both raw and cooked patties during storage $(P<0.05)$. Astaxanthin added at levels of 60 and/or $80 \mathrm{mg} / \mathrm{kg}$ showed a greater antioxidant effect than ascorbate and metabisulphite. The presence of astaxanthin, like that of ascorbate, decreased the oxysterols levels of cooked patties with regard to controls. The amount of volatiles released from the cooked patties was also reduced by astaxanthin. This effect was not observed for ascorbate or metabisulphite. Astaxanthin in lamb patties at levels of $60-80 \mathrm{mg} / \mathrm{kg}$ could improve raw and cooked lamb patty oxidative stability during refrigerated aerobic storage, protect their lipids against thermal degradation more than ascorbate and metabisulphite, and reduce oxysterols formation during cooking in a similar way to ascorbate.

\section{Keywords}

Natural antioxidant; lamb; meat preparation; oxysterols; volatile compounds; natural colorant 


\section{Introduction}

Lipid oxidation is considered as an inevitable, irreversible and complex process that occurs in all food matrices during processing, storage or distribution, and remains a major concern in terms of loss of sensory quality besides loss of nutritional and economic value (Estévez, 2017). Furthermore, during oxidation, several reactive species (RS) are generated, which are the main agents responsible for health disorders in the consumer (Bekhit, Hopkins, Fahri, \& Ponnampalam, 2013). For example, in meat, as in other foods of animal origin, RS can react with cholesterol, originating the formation of at least 60 different oxidation products (Razzazi-Fazeli, Kleineisen, \& Luf, 2000) which have been found to be mutagenic, cytotoxic and carcinogenic (Min et al., 2016). Furthermore, the presence of some of them in food has been associated with arteriosclerosis and neurodegenerative diseases (Poli, Biasi, \& Leonarduzzi, 2013; Savage, Dutta, \& Rodriguez-Estrada, 2002).

The use of antioxidant additives by the meat industry has proved to be a good strategy to delay or prevent oxidation processes (Liu, Xu, Dai, \& Ni, 2015). Thus, ascorbic acid (or ascorbate) is a commonly used antioxidant additive in processed meat. This is a water-soluble molecule, used as an additive according to the principle of 'just enough', and is considered to have no toxic effect on consumers (Varvara et al., 2016). Moreover, sulphur dioxide, or its precursors such as metabisulphite, although less commonly used is allowed at maximum levels of $450 \mathrm{mg} / \mathrm{kg}$ in specific meat preparations such as burger meat (SANCO, 2017). The functions of this additive are to reduce microbial growth, protect against oxidation and enhance the red colour of meat (Mathenjwa, Hugo, Bothma, \& Hugo, 2012; Ough \& Were, 2005). 
There is growing consumer demand for natural antioxidants over synthetic ones that have been associated with toxicological or antinutritional effects, such as sulphur dioxide, butylhydroxytoluene or butylhydroxyanisol (Shah, Bosco, \& Mir, 2014). This has driven the use of natural materials or their extracts rich in antioxidant molecules as meat product ingredients, in order to delay oxidation processes, besides contributing to nutritional improvement (Kumar, Yadav, Ahmad, \& Narsaiah, 2015; Shah et al., 2014; Villalobos et al., 2015).

Astaxanthin (3,3'-dihydroxy- $\beta, \beta$-carotene-4,4'-dione) is a red xanthophyll carotenoid which is naturally found in crustaceans, salmonids and some types of bird feathers, yeasts and algae, Haematococcus pluvialis being the main source of this antioxidant for human consumption (Ambati, Moi, Ravi, \& Aswathanarayana, 2014; Guerin, Huntley, \& Olaizola, 2003; Kidd, 2011; Kobayashi et al., 1997). Interest in astaxanthin extracts in the nutritional supplement and food industries is growing (Higuera-Ciapara, Félix-Valenzuela, \& Goycoolea, 2006). Several functions have been attributed to this carotene regarding its use as food ingredient, i.e. natural colorant and antioxidant, or as a nutritional supplement, i.e. antioxidant, anti-inflammatory and anti-diabetic activity in the organism (Ambati et al., 2014; Guerin et al., 2003; Higuera-Ciapara et al., 2006). It is well known that its antioxidant capacity is greater than that shown by other carotenoid compounds (Ambati et al., 2014; Naguib, 2000).

In spite of the increasing interest within the food industry in extending the use of astaxanthin, there are few studies about the effect of the presence of this compound on meat quality. To the best of our knowledge, it has been reported that feeding of pigs (Carr, Johnson, Brendemuhl, \& Gonzalez, 2010) or chickens (Perenlei et al., 2014) with appropriate doses of this carotene can lead to an improvement in meat colour and oxidative stability. Furthermore, Abdelmalek et al. (2016) demonstrated an antioxidant effect of astaxanthin in marinated chicken steaks during refrigerated storage. No studies have been carried out, however, on the effect of astaxanthin on 
the quality of red meat and specifically that of lamb, which is widely consumed in European Mediterranean countries where light lamb meat is considered a luxury meat (Linares, Bórnez, \& Vergara, 2007).

Taking all this into account, the aims of the present study were to evaluate the effect of the addition of different levels of a commercial astaxanthin powder on the oxidative lipid stability of raw lamb patties during refrigerated and frozen storage and during their heat treatment and refrigerated storage of cooked patties. For a better assessment of this effect, patties without antioxidants and patties with ascorbate and metabisulphite were included in the study.

\section{Materials and Methods}

\subsection{Patty manufacturing and sampling}

The meat used in this experiment was obtained from the legs of 12 lambs that were reared under a conventional system consisting of suckling until $13.5 \mathrm{~kg}$ body weight followed by weaning and fattening on a complete pelleted diet until a target body weight of $27 \mathrm{~kg}$ was achieved, as described by Santos, Giráldez, Mateo, Frutos and Andrés (2018). Legs were obtained from the cold carcasses at $24 \mathrm{~h}$ post mortem, and deboned. The flesh was then cut into approximately 3$\mathrm{cm}^{3}$ pieces and trimmed of any visible fat. The meat pieces from the 12 lambs were mixed together, vacuum packaged in three different packaging bags and frozen-stored for a period of 89 months at $-18{ }^{\circ} \mathrm{C}$. Afterwards, the meat was thawed for $24 \mathrm{~h}$ at $5{ }^{\circ} \mathrm{C}$ in order to prepare three batches of patties, each one with the meat from one packaging bag. The patty batches were prepared on three different days at the Food Processing Hall of the Department of Food Hygiene and Technology (University of León, León, Spain). 
Each batch (weighing $3.5 \mathrm{~kg}$ ) consisted of seven 500-g sub-batches of patties according to the type or amount of antioxidant added, i.e. antioxidant treatment, which were labelled as CON (no addition of antioxidant), SULP (addition of $450 \mathrm{mg}$ of sodium metabisulphite per $\mathrm{kg}$ of patty mixture: 450 ppm; Panreac, Barcelona, Spain), ASC (500 ppm of sodium ascorbate; Panreac), AST20 (20 ppm of astaxanthin), AST40 (40 ppm of astaxanthin), AST60 (60 ppm of astaxanthin) and AST80 (80 ppm of astaxanthin). The astaxanthin added to the patties was part of a commercial dietary supplement (Astaxantina-Lider, Naturlider, Ciudad Real, Spain) containing astaxanthin (1\%) extracted from $H$. pluvialis, and excipients: maltodextrin, magnesium stearate and silicon dioxide. The amount of supplement added to the corresponding patties was adjusted to the above-mentioned astaxanthin levels. The amount of sodium ascorbate used was in the range generally applied in processed meat (400-600 ppm; Feiner, 2006), that of metabisulphite was the maximum allowed level for burger meat (SANCO, 2017), and those of astaxanthin were such that the amount contained in a $100-\mathrm{g}$ patty was close to the dose recommended for astaxanthin as a dietary supplement for humans, i.e. approximately $6 \mathrm{mg} /$ day (Ambati et al., 2014). The antioxidant potential of the antioxidants used in the experiment was determined in the lab using 2,2-diphenyl-1-picrylhydrazyl (DPPH; Serpen et al., 2012) and the results obtained for sodium metabisulphite, sodium ascorbate, and astaxanthin, which was previously extracted from the dietary supplement with ethyl acetate, were respectively $0.34,4.07$ and 0.86 mmol Trolox equivalents per $\mathrm{g}$ of substance.

The formulation of patties was as follows: $79.5 \%$ of lean minced leg lamb (using a butcher's mincer equipped with a $5-\mathrm{mm}$ diameter sieve), $4 \%$ of potato starch, $15 \%$ of water and $1.5 \%$ of common salt. Moreover, depending on the treatment, the corresponding antioxidant was added to the patties. All the components were manually mixed for $2 \mathrm{~min}$. Finally, five 100-g patties were formed from each sub-batch; out of those, three patties were used to evaluate the oxidative status 
and stability when raw refrigerated, one when raw frozen, and the other when cooked and reheated (Table 1). The raw patties were analysed for thiobarbituric reactive substances (TBARS), colour, Eh and $\mathrm{pH}$ on the preparation day and after 5 and 11 days of refrigerated storage $\left(4^{\circ} \mathrm{C}\right)$ on polystyrene foam trays wrapped with polyvinyl chloride cling film, using one patty per storage day. The frozen patties, which had been previously wrapped with polyvinyl chloride cling film and then stored for 90 days at $-18{ }^{\circ} \mathrm{C}$, were analysed just after thawing ( 1 day at $4{ }^{\circ} \mathrm{C}$ ) for TBARS. For the cooked patties, a patty from each antioxidant treatment was first stored raw under refrigeration $\left(4{ }^{\circ} \mathrm{C}\right)$ for 5 days, then cooked in a convection oven at $150{ }^{\circ} \mathrm{C}$ for 15 min until reaching a core temperature of $70{ }^{\circ} \mathrm{C}\left( \pm 2{ }^{\circ} \mathrm{C}\right)$, and subsequently divided into four quarters. One quarter was vacuum packaged and frozen at $-18{ }^{\circ} \mathrm{C}$ for up to 3 weeks before analysis of TBARS, cholesterol oxides and volatile compounds. The other three quarters were stored under refrigeration $\left(4{ }^{\circ} \mathrm{C}\right)$ on polystyrene trays covered with polyvinylchloride cling film for 2 (two quarters) and 4 days (one quarter). One of the quarters stored for 2 days, and the quarter stored for 4 days were immediately frozen under vacuum (up to 3 weeks) before analysis of TBARS. The other quarter stored for 2 days was first reheated in a domestic microwave (400 W) for 2 min and then frozen under vacuum (up to 3 weeks) before analysis of cholesterol oxides. Moreover, a digital photograph of a raw patty per treatment and batch was taken just after patty preparation. A photo of a patty from each treatment has been included in Fig. 1 in order to show the reader the effect of the used levels of astaxanthin on the colour of the patties. The photos were taken using a digital reflex camera (400D EOS camera; Canon, Ohta-ku, Tokyo) equipped with a 10.1-megapixel CMOS sensor and EF-S 18-55 $\mathrm{mm}$ lens. The operating conditions were as follows: camera in a horizontal position $40 \mathrm{~cm}$ above the patty, mode ISO 800, shutter speed 1/40, manual focus (MF), diaphragm aperture F11, exposure compensation 
$-2 / 3$, fluorescent white balance mode and flash on. Patties were placed on a table, and a matt white sheet was placed underneath the samples.

\subsection{Instrumental and chemical analysis}

The values of $\mathrm{pH}$ and Eh were determined in duplicate using a BasiC $20 \mathrm{pH}$ meter (Crison Instruments, Barcelona, Spain) equipped with a 52-32 $\mathrm{pH}$ penetration electrode and a 32-61 redox platinum electrode, respectively, by inserting the electrodes into a ball-shaped 50-g raw patty sample. TBARS of raw and cooked patties was analysed following the procedure described by Nam and Ahn (2003). The instrumental colour parameters lightness $\left(L^{*}\right)$, redness $\left(a^{*}\right)$ and yellowness $\left(b^{*}\right)$ were determined directly on the upper surface of the raw patty, in triplicate, using a Konica Minolta CM-700d colorimeter (Osaka, Japan) with D65 illuminant in SCI mode, an 11-mm aperture for illumination and $8 \mathrm{~mm}$ for measurement, and a visual angle of $10^{\circ}$.

The volatile compounds were analysed by gas chromatography coupled with mass spectrometry using the equipment and following the method described by Vieira et al. (2012) with modifications. Briefly, a 2-g aliquot of cooked patty was placed in 15-ml screw-cap vials (Agilent Technologies, Santa Clara, CA, USA). The vials were agitated intermittently (500 rpm, 5s on, $2 \mathrm{~s}$ off) at $140{ }^{\circ} \mathrm{C}$ for $40 \mathrm{~min}$ in the chromatograph autosampler in order to extract the volatile compounds into the headspace. The syringe needle temperature was $120{ }^{\circ} \mathrm{C}$, and the filling and injection speeds were 50 and $250 \mu \mathrm{l} / \mathrm{s}$, respectively. The headspace injection volume was $1 \mathrm{ml}$, and the injector had a temperature of $260^{\circ} \mathrm{C}$ and operated in the splitless mode. The volatile compounds were separated with a DB-5MS column $(60 \mathrm{~m} \times 0.25 \mathrm{~mm} \mathrm{ID} \times 0.25 \mu \mathrm{m}$ film thickness; J\&W Scientific, Folsom, CA, USA) using helium as carrier gas with a flow rate of 1.5 
$\mathrm{ml} / \mathrm{min}$. The oven conditions were as follows: initial temperature of $38{ }^{\circ} \mathrm{C}$ held for $1 \mathrm{~min}$, increased to $50{ }^{\circ} \mathrm{C}$ at $10{ }^{\circ} \mathrm{C} / \mathrm{min}$, then to $146{ }^{\circ} \mathrm{C}$ at $4{ }^{\circ} \mathrm{C} / \mathrm{min}$, then to $200{ }^{\circ} \mathrm{C}$ at $20{ }^{\circ} \mathrm{C} / \mathrm{min}$ and finally to $250{ }^{\circ} \mathrm{C}$ at $50{ }^{\circ} \mathrm{C} / \mathrm{min}$, maintaining this temperature for $11 \mathrm{~min}$. The transfer-line temperature was $260{ }^{\circ} \mathrm{C}$. The mass spectrometer operated with an electron source temperature of $240{ }^{\circ} \mathrm{C}$, electron energy and emission currents of $70 \mathrm{eV}$ and $35 \mu \mathrm{A}$, respectively, a quadrupole temperature of $190{ }^{\circ} \mathrm{C}$, and a scanner range from $\mathrm{m} / \mathrm{z} 40$ to $\mathrm{m} / \mathrm{z} 230$. Identification of the volatile compounds detected was carried out by comparing their spectra with those contained in the NIST/EPA/NIH-98 Mass Spectral Database, together with personal interpretation, and their linear retention indices, calculated from the retention times of a series of $n$-alkanes (Hydrocarbons/C5-C20; Sigma-Aldrich, St. Louis, MO, USA), with those from the literature. The results were expressed in ng equivalents of hexanal $/ \mathrm{ml}$ of headspace.

Cholesterol oxidation products (COPs) were determined in cooked and reheated patties using the method described by Grau, Codony, Grimpa, Baucells and Guardiola (2001) with a few modifications. The patty sample was first lyophilized, and the lipids from $1 \mathrm{~g}$ of freeze-dried patty sample were extracted using a mixture of chloroform and methanol $(1: 1, \mathrm{v} / \mathrm{v})$; then, $1 \mathrm{ml}$ of 19-hydroxycholesterol $(20 \mu \mathrm{g} / \mathrm{ml})$ was added as an internal standard. After homogenization, the mixture was filtered using a vacuum, and then $9 \mathrm{ml}$ of aqueous $0.88 \% \mathrm{KCl}(\mathrm{w} / \mathrm{v})$ and two drops of $6 \mathrm{M} \mathrm{HCl}$ were added to the sample. Afterwards, the sample was centrifuged, and the lower layer obtained was placed in a dark flask. Ten millilitres of $1.5 \mathrm{M}$ methanolic $\mathrm{KOH}$ and $500 \mu \mathrm{l}$ of BHT were added, and the mixture was kept in an orbital shaker (100 rpm) for $24 \mathrm{~h}$ to complete the saponification reaction, under $\mathrm{N}_{2}$ atmosphere in darkness and at room temperature $\left(20{ }^{\circ} \mathrm{C}\right)$. The unsaponifiable matter was then extracted and purified by solid-phase extraction following the procedure described by Guardiola, Codony, Rafecas and Boatella (1995). Finally, oxysterols were derivatized to trimethylsilyl ethers, and the resulting solution was analysed using a gas 
chromatograph coupled with a mass spectrometer. A total of $1.5 \mu \mathrm{l}$ was injected in splitless mode and at an injector temperature of $250{ }^{\circ} \mathrm{C}$. Helium was used as carrier gas at a flow rate of $0.6 \mathrm{ml} / \mathrm{min}$. The column used was a VF-5 ms (CP8947) capillary column (50 $\mathrm{m} \times 250 \mu \mathrm{m} \times 0.25 \mu \mathrm{m}$; Varian, Palo Alto, CA, USA). The oven conditions were: initial oven temperature $75{ }^{\circ} \mathrm{C}$, increased to $250{ }^{\circ} \mathrm{C}$ at $30{ }^{\circ} \mathrm{C} / \mathrm{min}$, then to $290{ }^{\circ} \mathrm{C}$ at $8{ }^{\circ} \mathrm{C} / \mathrm{min}$, and finally to $292{ }^{\circ} \mathrm{C}$ at $0.05{ }^{\circ} \mathrm{C} / \mathrm{min}$. The transfer-line temperature was $280{ }^{\circ} \mathrm{C}$. The mass spectrometer operated with an electron source temperature of $260{ }^{\circ} \mathrm{C}$, electron energy and emission currents of $70 \mathrm{eV}$ and $35 \mu \mathrm{A}$, respectively, a quadrupole temperature of $200{ }^{\circ} \mathrm{C}$, and a scanner range from $\mathrm{m} / \mathrm{z} 40$ to $\mathrm{m} / \mathrm{z} 500$. Identification was carried out by comparing the peak retention times of the sample with those of the standards analysed under the same conditions as the samples, and the peak spectra with those contained in the NIST/EPA/NIH-98 Mass Spectral Database, together with personal interpretation. The oxysterols used as external standards for identification and

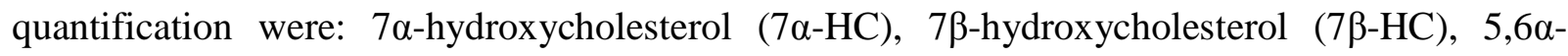
epoxycholesterol $\quad(\alpha-\mathrm{CE}), \quad 5,6 \beta$-epoxycholesterol $\quad(\beta-\mathrm{CE}), \quad$ cholestanetriol $\quad(\mathrm{CT}), \quad 25-$ hydroxycholesterol (25-HC) and 7-ketocholesterol (7-KC) (Steraloids, Inc., Wilton, New Hampshire, USA). The results were expressed in $\mu \mathrm{g} / \mathrm{g}$ of meat. Furthermore, an oxysterol different from the standard, cholesta-3,5-dien-7-one (CDO), was identified by its spectrum and was quantified as equivalents of $\alpha-\mathrm{CE}(\mu \mathrm{g} / \mathrm{g}$ of meat).

\subsection{Statistical analysis}

The data from the chemical characteristics of the refrigerated raw patties and the TBARS values of the refrigerated cooked patties were analysed using the general linear model analysis of 
variance (ANOVA) with antioxidant treatment as fixed factor and storage time as repeatedmeasures variable. TBARS generation during frozen storage and the data on the volatile compounds were analysed by univariate ANOVA with antioxidant treatment being the fixed factor. Data for oxysterol contents in cooked samples and reheated samples were separately analysed by ANOVA (antioxidant treatment was the fixed factor). Furthermore, mean differences in oxysterols between cooked and reheated lamb within each antioxidant treatment were calculated using the Student`s T test. Post hoc analyses of the ANOVA results for antioxidant treatment factor were carried out with the Tukey-Kramer test, and for time in repeatedmeasurement factor (storage day) with the Bonferroni test. The significance level was always $P<$ 0.05. Analyses were preformed using SPSS Statistics software (version 23; IBM, Somers, NY, USA).

\section{Results and Discussion}

\subsection{Refrigerated-stored fresh patties}

The quality characteristics of the refrigerated patties stored under aerobic conditions are shown in Table 2. Among the traits evaluated, redox potential was the only characteristic not affected by antioxidant treatment $(P>0.05)$. The $\mathrm{pH}$ values of the patties with added antioxidant did not differ from those of $\mathrm{CON}$; however, the $\mathrm{pH}$ of ASC patties, which showed the highest mean values, differed from those of AST patties with astaxanthin concentrations equal to or higher than $40 \operatorname{ppm}(P<0.05)$.

The TBARS levels at day 0 suggest the development of initial lipid oxidation in the meat during the previous deboning, cutting, vacuum frozen storage (8-9 months) and patty manufacture. The 
experimental refrigerated storage of patties led to a sharp increase in the TBARS concentration. These high rates of TBARS increase might be partially attributed to the initial oxidation of lamb lipids, i.e. high TBARS levels at day 0. Neither the presence of sulphites nor that of ascorbate resulted in a decrease in the increments of TBARS due to the storage as compared to CON patties. In agreement, Bañón, Díaz, Rodríguez, Garrido and Price (2007) did not observe lipid antioxidant effect of metabisulphite (used at a level equivalent to $100 \mathrm{ppm}$ of sulphur dioxide) in beef patties during a 9-day refrigerated aerobic display period. Also in agreement, SánchezEscalante, Djenane, Torrescano, Beltrán and Roncalés (2001) observed that ascorbic acid at 500 ppm was ineffective in preventing lipid oxidation when added to ground beef during refrigerated storage under a high-oxygen modified atmosphere. To explain this, the authors hypothesised that the antioxidant effect of ascorbic acid, which would depend on its concentration, could be decreased by factors related to the meat preparation matrix such as salt presence, degree of mincing and oxygen concentration. Furthermore, taking into account our results, the initial oxidation of meat (at day 0 ) might be added to that listing of potential reasons.

The addition of astaxanthin at levels of 60 and $80 \mathrm{ppm}$, however, significantly reduced the TBARS formation $(P<0.05)$ during the patty storage with regard to CON patties. Moreover, the addition of $80 \mathrm{ppm}$ of astaxanthin showed significantly $(P<0.05)$ higher effectiveness in preventing lipid oxidation than the addition of $450 \mathrm{ppm}$ of sodium metabisulphite and $500 \mathrm{ppm}$ of sodium ascorbate, which, as said before, did not show a significant protective effect with respect to CON values. Moreover, it is noteworthy that the time-related increase in TBARS showed a significant interaction with antioxidant treatment, which consisted of different rates of increase in TBARS values between treatments, i.e. higher rates for CON, SULP and ASC than for AST patties (data not shown). The antioxidant effect of astaxanthin on raw-meat lipid 
oxidation has been previously assessed by Abdelmalek et al. (2016) when adding 10 ppm of astaxanthin to marinated chicken steaks.

As regards instrumental colour, the addition of astaxanthin to the patties originated, as expected, a sharp increment in $a^{*}$ and, to a lesser extent, in $b^{*}$, and a decrement in $L^{*}$ (Table 2). On the other hand, instrumental colour characteristics of CON, SULP and ASC patties were apparently not different $(P<0.05)$. However, when the AST-added treatments are not considered, i.e. when repeated measures ANOVA was applied only to CON, SULP and ASC (data not shown in tables), the patties with sodium ascorbate showed a significantly higher degree of redness than CON $(P<0.05)$, while SULP patties were not significantly different either from CON or from ASC. This confirms the reported effectiveness of ascorbate in inhibiting metmyoglobin formation (Sánchez-Escalante et al., 2001). However, in contrast, the previously demonstrated protective effect of metabisulphite (at a level equivalent to $100 \mathrm{ppm}$ of $\mathrm{SO}_{2}$ ) on patty-surface discoloration (Bañón et al., 2007) was not statistically evidenced in this study. This lack of effect could be at least partially attributed to the initial oxidation of lipids at the moment of storage, which would have promoted the metmyoglobin formation (Faustman, Sun, Mancini, \& Suman, 2010) and thus hindered the effect of of metabisulphite on improving the colour of the patties with respect to the colour of CON.

\subsection{Frozen-stored patties}

The increase in TBARS levels in raw lamb patties after 3 months of frozen storage (at $-18{ }^{\circ} \mathrm{C}$ ) is depicted in Fig. 2. The generation of TBARS did not exceed $1 \mathrm{mg} / \mathrm{kg}$ of meat except for the SULP treatment. Thus, the addition of metabisulphite to the patties significantly increased TBARS formation during frozen storage compared to the control and the rest of treatments. On 
the other hand, the addition of ascorbate practically stopped frozen storage-related TBARS formation. The greater amount of TBARS in the frozen SULP patties might be attributed to the formation of reactive sulphur species promoting lipid oxidation (Brannan, 2010), which would have somehow originated from the metabisulphite during the 3-month storage. In the frozen patties, the protective effect of astaxanthin against lipid oxidation, which in contrast was observed in refrigerated patties, was not evidenced in this study, i.e. the TBARS concentration increments due to frozen storage in AST patties were not different from those of CON patties $(P$ $>0.05)$. To our knowledge, the effect of astaxanthin on lipid stability of frozen red meat has not been studied before and thus it was not possible to compare our results with literature. The lack of effect could be at least partially explained by the loss of astaxanthin content in patties during frozen storage. Astaxanthin significant losses during frozen storage of fish have been previously detected (Erickson, 1997; Jensen, Skibsted, Bertelsen, Birk and Jokumsen, 1998), with losses depending on the storage conditions and period. Those authors explained that astaxanthin losses in frozen fish are enhanced by a reduced water activity and the eventual diffusion of oxygen through the oxygen-permeable packaging material, and suggested disruption of tissue as a contributing factor. The initial extend of lipid oxidation in meat (at the moment of frozen storage), which in this study was noticeable, might also be considered as another contributing factor.

\subsection{Cooked patties}

The lipid stability of the cooked patties during refrigerated storage as quantified by TBARS analysis is shown in Table 3. There were no significant differences between CON and SULP or between CON and ASC patties. Among these three treatments, the addition of ascorbate resulted 
in the lowest mean value and addition of metabisulphite the highest, so that the ASC levels differed statistically $(P<0.05)$ from the SULP levels. The use of astaxanthin as an antioxidant at levels of $40 \mathrm{ppm}$ or higher decreased the lipid oxidation of cooked patties compared to CON patties, and there was a tendency for lower TBARS values with greater astaxanthin addition. The protective effect of astaxanthin against lipid oxidation in cooked patties was comparable to that observed in fresh patties; therefore, astaxanthin seems not to be affected by heat treatment. This is consistent with the high stability of astaxanthin when subjected to heat treatments of $70-90{ }^{\circ} \mathrm{C}$ (Ambati, Ravi, \& Gokare Aswathanarayana, 2007). During storage, TBARS values increased ( $P$ $<0.05)$ but at different rates depending on the treatment, which explains the statistical effect $(P<$ 0.05) found for the interaction day $\times$ treatment. During the entire storage period, the TBARS level increased by approximately $4 \mathrm{ppm}$ in CON patties, $5 \mathrm{ppm}$ in SULP patties, $3 \mathrm{ppm}$ in ASC patties, 2 ppm in AST20 and AST40 patties, and by less than 1 ppm in AST60 and AST80 patties (data not shown).

The COP levels ( $\mu$ g per g meat) in lamb patties for each of the treatments are shown in Table 4; CT and 25-HC were not detected (detection limit $0.1 \mu \mathrm{g} / \mathrm{g}$ ) and thus were not included in the Table for brevity. Because heating is a main factor for COP formation in meat (Brzeska, Szymczyk, \& Szterk, 2016; Khan et al., 2015; Min et al., 2016), and in order to know the effect of a second heat treatment on their formation, COP levels were determined in both recently cooked lamb patties and in patties reheated ( 2 days after cooking) using a microwave. As shown in the Table, reheating resulted in increased COP levels (approximately $30 \%$ higher), which were significantly different regarding total COPs in CON and SULP patties and 7-KC and $\beta$-CE in CON and AST20 patties, respectively. 
The most abundant COPs in cooked lamb patties (with and without reheating) were 7 -KC, $\beta$-CE, $7 \alpha-\mathrm{HC}$ and $7 \beta-\mathrm{HC}$, which have already been found as major COPs in cooked meat products (Orczewska-Dudek, Bederska-Łojewska, Pieszka, \& Pietras, 2012). The amounts found in this study for cooked (not reheated) CON patties were approximately four times higher than those detected in lamb steaks in a previous study (Andrés et al., 2014). The difference might be partially attributed to the mincing process and the presence of common salt in the patties, as well as variation in the cooking conditions.

The mean levels of total COPs decreased in all the antioxidant-treated patties compared to CON patties although only a near to significant difference due to antioxidant treatment was found in microwave reheated patties $(P<0.1)$. Moreover, the mean levels of total COPs for patties containing astaxanthin tended to decrease with the astaxanthin level, although significant differences between treatments with astaxanthin were not detected in ANOVA. In partial agreement, Osada, Hoshina, Nakamura and Sugano (2000) found inhibition of cholesterol oxidation in meat due to the use of another radical scavenging antioxidant, i.e. apple polyphenols, and related fatty acid oxidation to cholesterol oxidation in meat products.

Among the major COPs detected, treatment significantly affected the amount of $7 \alpha-\mathrm{HC}$ and 7 $\mathrm{KC}$, which have been associated with neurodegenerative and cancerogenic diseases (Brzeska et al., 2016; Poli et al., 2013). With regard to 7-KC, metabisulphite, ascorbate and astaxanthin at levels $\geq 40 \mathrm{mg} / \mathrm{kg}$ showed a significant decreasing effect $(P<0.05)$ compared to CON cooked patties. On the other hand, the $7 \alpha-\mathrm{HC}$ levels were significantly higher $(P<0.05)$ in SULP patties than in the other patties containing antioxidants, although no differences were detected between SULP and AST20 cooked (not reheated) patties and between SULP and CON patties. 
Table 5 shows the volatiles identified in the headspace of cooked lamb patties. Only those compounds showing levels higher than $0.4 \mathrm{ng}$ hexanal equivalents per $\mathrm{ml}$ of headspace are included for brevity. Volatiles were classified into eight chemical families: aliphatic hydrocarbons (five compounds), aliphatic aldehydes (21), aliphatic ketones (four), aliphatic alcohols (eight), furans (four), sulphur compounds (two) and benzene compounds (five). Most of them, i.e. the major part of the straight-chain hydrocarbons, aliphatic aldehydes, ketones and alcohols and alkylfurans, are presumably produced by lipid degradation (Resconi, Escudero, \& Campo, 2013; Yang et al., 2015), which would have originated due to thermal oxidation during both patty cooking and head-space extraction of volatiles.

The antioxidant treatment variable showed a significant effect on the total sum of volatiles and specifically on the sums of the above-mentioned chemical families (mainly composed of secondary products of lipid oxidation), as well as on most of the individual compounds within these families $(P<0.05$; Table 5). Statistical differences $(P<0.05)$ were found between CON patties and AST40, AST60 and/or AST80 patties for octane, tridecane and tetradecane, the aliphatic aldehydes with less than sixteen carbons, the aliphatic ketones with seven and eight carbons and the four furans detected. Overall, the use of astaxanthin resulted in a dose-dependent decrease in those volatiles significantly affected. The results, thus, suggest that astaxanthin produced a protective effect against lipid thermal degradation and thus reduced the levels of lipid derived volatiles. This effect could be explained by the capacity of astaxanthin to scavenge lipid radicals, resulting in inhibition of the lipid oxidation free radical chain reaction (Skibsted, 2012). A decreasing effect of dietary natural antioxidants on the levels lipid derived volatiles in cooked lamb has been previously suggested by Resconi et al. (2010), who found a lower presence of ketones and unsaturated aldehydes in meat from lambs fed on pasture than in that from lambs fed on concentrate. They attributed this difference to a high lipid oxidative stability in the former due 
to the high concentration of antioxidants in fresh pastures. However, in partial disagreement with our study, they found that diet (levels of natural antioxidants in meat) did not affect the levels of volatile saturated aldehydes in meat. Notwithstanding, both studies are not totally comparable because, unlike the study by Resconi et al., in our study the fatty acid profile of meat would be similar between treatments. Moreover, the natural antioxidants involved in each study were different.

On the other hand, the use of or metabisulphite (SULP) or ascorbate (ASC) had no significant effect on the level of volatile compounds in the head space with regard to CON patties except for 2-ethyl-1-hexanol and 2-hexylfuran, the levels of which were higher in ASC patties $(P<0.05)$. Ascorbate, was thus not able to protect against lipid oxidation during lamb heating in spite of its demonstrated ability to reduce lipid oxidation during refrigerated storage (Jayathilakan, Sharma, Radhakrishna, \& Bawa, 2007).

The changes in volatile profile due to astaxanthin could affect lamb patty flavour, probably towards a milder flavour. This is because among the volatiles detected and significantly affected, the aldehydes such as hexanal, 2-nonenal, 2-decenal, 2,4-decadienal or some of the ketones such as 2-heptanone, have been highly correlated with flavour modifications in lamb (Descalzo \& Sancho, 2008; Resconi et al., 2010; Bueno, Resconi, Campo, Cacho, Ferreira, \& Escudero, 2011), with some of them providing lamb with meaty flavours.

\section{Conclusion}

The findings of this study suggest that the inclusion of natural astaxanthin at levels from 20 to 80 $\mathrm{mg} / \mathrm{kg}$ in meat preparations, particularly in raw and cooked lamb patties, can be used to delay lipid oxidation during their aerobic refrigerated storage, thus contributing to improve their shelf life. Furthermore, astaxanthin demonstrate a protective effect on lipids, including fatty acids and 
cholesterol, against their thermal degradation due to cooking. To some extent those effects appeared to be dose dependent and become greater than the effects shown by other conventional antioxidants, i.e. ascorbate and metabisulphite. In contrast, results suggested that astaxanthin as lipid antioxidant can be less effective in frozen storage as compared with refrigerated storage, since an antioxidant effect of astaxathin during a 3-month frozen storage of patties could not be evidenced.

\section{Acknowledgments}

This study has been funded with support from the Consejería de Educación, Comunidad de Castilla y León and the European Fund for Regional Development, project CSI047P17. D.E. Carballo is grateful for being given a doctoral grant from CONACYT (MEX/ Ref. 288189). We acknowledge María Mercedes Pérez Rosales for her support in the laboratory work and numerical calculations.

\section{References}

Abdelmalek, B. E., Sila, A., Ghlissi, Z., Taktak, M. A., Ayadi, M. A., \& Bougatef, A. (2016). The Influence of Natural Astaxanthin on the Formulation and Storage of Marinated Chicken Steaks. Journal of Food Biochemistry, 40(4), 393-403.

Ambati, R. R., Moi, P., Ravi, S., \& Aswathanarayana, R. (2014). Astaxanthin: Sources, Extraction, Stability, Biological Activities and Its Commercial Applications-A Review. Marine Drugs, 12(1), 128-152.

Ambati, R. R., Ravi, S., \& Gokare Aswathanarayana, R. (2007). Stabilization of astaxanthin in edible oils and its use as an antioxidant. Journal of the Science of Food and Agriculture, 87(6), 957-965. 
Andrés, S., Huerga, L., Mateo, J., Tejido, M. L., Bodas, R., Morán, L., ... Giráldez, F. J. (2014). The effect of quercetin dietary supplementation on meat oxidation processes and texture of fattening lambs. Meat Science, 96(2), 806-811.

Bañón, S., Díaz, P., Rodríguez, M., Garrido, M. D., \& Price, A. (2007). Ascorbate, green tea and grape seed extracts increase the shelf life of low sulphite beef patties. Meat Science, 77(4), 626-633.

Bekhit, A. E.-D. A., Hopkins, D. L., Fahri, F. T., \& Ponnampalam, E. N. (2013). Oxidative Processes in Muscle Systems and Fresh Meat: Sources, Markers, and Remedies. Comprehensive Reviews in Food Science and Food Safety, 12(5), 565-597.

Brannan, R. G. (2010). Reactive Sulfur Species Act as Prooxidants in Liposomal and Skeletal Muscle Model Systems. Journal of Agricultural and Food Chemistry, 58(6), 3767-3771.

Brzeska, M., Szymczyk, K., \& Szterk, A. (2016). Current Knowledge about Oxysterols: A Review. Journal of Food Science, 81(10), R2299-R2308.

Bueno, M., Resconi, V.C., Campo, M.M., Cacho, J., Ferrerira, V., Escudero, A. (2011). Gas chromatographic-olfactometric characterisation of headspace and mouthspace key aroma compounds in fresh and frozen lamb meat. Food Chemistry, 129, 1909-1918.

Mónica Bueno a, Virginia C. Resconi b, M. Mar Campo b, Juan Cacho a, Vicente Ferreira a, Ana Escudero

Carr, C. C., Johnson, D. D., Brendemuhl, J. H., \& Gonzalez, J. M. (2010). Fresh Pork Quality and Shelf-Life Characteristics of Meat from Pigs Supplemented with Natural Astaxanthin in the Diet. The Professional Animal Scientist, 26(1), 18-25.

Descalzo, A. M., \& Sancho, A. M. (2008). A review of natural antioxidants and their effects on oxidative status, odor and quality of fresh beef produced in Argentina. Meat Science, 79(3), 423-436.

Erickson, M. C. (1997). Lipid Oxidation: Flavor and Nutritional Quality Deterioration in Frozen Foods. In M. C. Erickson \& Y.-C. Hung (Eds.), Quality in Frozen Foods (First, pp. 141173). Boston, MA: Springer US.

Estévez, M. (2017). What's New in Meat Oxidation. In P. P. Purslow (Ed.), New Aspects of Meat Quality (1st ed., pp. 91-109). Buenos Aires, Argentina: Woodhead Publishing.

Faustman, C., Sun, Q., Mancini, R., Suman, S. (2010). Myoglobin and lipid oxidation interactions: Mechanistic bases and control. Meat Science, 86, 86-94.

Feiner G. (2006). Meat products handbook. Cambridge, UK: Woodhead Publishing (Chapter 7). 
Grau, A., Codony, R., Grimpa, S., Baucells, M. D., \& Guardiola, F. (2001). Cholesterol oxidation in frozen dark chicken meat: influence of dietary fat source, and $\alpha$-tocopherol and ascorbic acid supplementation. Meat Science, 57(2), 197-208.

Guardiola, F., Codony, R., Rafecas, M., \& Boatella, J. (1995). Comparison of three methods for the determination of oxysterols in spray-dried egg. Journal of Chromatography A, 705(2), 289-304.

Guerin, M., Huntley, M. E., \& Olaizola, M. (2003). Haematococcus astaxanthin: applications for human health and nutrition. Trends in Biotechnology, 21(5), 210-216.

Higuera-Ciapara, I., Félix-Valenzuela, L., \& Goycoolea, F. M. (2006). Astaxanthin: A Review of its Chemistry and Applications. Critical Reviews in Food Science and Nutrition, 46(2), 185196.

Jayathilakan, K., Sharma, G.K., Radhakrishna, K., Bawa, A.S. (2007). Antioxidant potential of synthetic and natural antioxidants and its effect on warmed-over-flavour in different species of meat. Food Chemistry, 105, 908-916.

K. Jayathilakan *, G.K. Sharma, K. Radhakrishna, A.S. Bawa

Jensen, C., Skibsted, L. H., Bertelsen, G., Birk, E., \& Jokumsen, A. (1998). Effect of dietary levels of fat, a-tocopherol and astaxanthin on colour and lipid oxidation during storage of frozen rainbow trout (Oncorhynchus mykiss) and during chill storage of smoked trout. Zeitschrift Fur Lebensmittel-Untersuchung Und -Forschung, 207, 189-196.

Khan, M. I., Min, J.-S., Lee, S.-O., Yim, D. G., Seol, K.-H., Lee, M., \& Jo, C. (2015). Cooking, storage, and reheating effect on the formation of cholesterol oxidation products in processed meat products. Lipids in Health and Disease, 14, 89.

Kidd, P. (2011). Astaxanthin, cell membrane nutrient with diverse clinical benefits and anti-aging potential. Alternative Medicine Review : A Journal of Clinical Therapeutic, 16(4), 355-64.

Kobayashi, M., Kakizono, T., Nishio, N., Nagai, S., Kurimura, Y., \& Tsuji, Y. (1997). Antioxidant role of astaxanthin in the green alga Haematococcus pluvialis. Applied Microbiology and Biotechnology, 48(3), 351-356.

Kumar, Y., Yadav, D. N., Ahmad, T., \& Narsaiah, K. (2015). Recent Trends in the Use of Natural Antioxidants for Meat and Meat Products. Comprehensive Reviews in Food Science and Food Safety, 14(6), 796-812.

Linares, M. B., Bórnez, R., \& Vergara, H. (2007). Effect of different stunning systems on meat quality of light lamb. Meat Science, 76(4), 675-681. 
Liu, F., Xu, Q., Dai, R., \& Ni, Y. (2015). Eff ects of natural antioxidants on colour stability, lipid oxidation and metmyoglobin reducing activity in raw beef patties. Acta Scientiarum Polonorum Technologia Alimentaria, 14(1), 37-44.

Mathenjwa, S. A., Hugo, C. J., Bothma, C., \& Hugo, A. (2012). Effect of alternative preservatives on the microbial quality, lipid stability and sensory evaluation of boerewors. Meat Science, 91(2), 165-172.

Min, J.-S., Khan, M. I., Lee, S.-O., Yim, D. G., Seol, K. H., Lee, M., \& Jo, C. (2016). Impact of Cooking, Storage, and Reheating Conditions on the Formation of Cholesterol Oxidation Products in Pork Loin. Korean Journal for Food Science of Animal Resources, 36(1), 23-8.

Naguib, Y. M. (2000). Antioxidant activities of astaxanthin and related carotenoids. Journal of Agricultural and Food Chemistry, 48(4), 1150-4.

Nam, K. C., \& Ahn, D. U. (2003). Use of antioxidants to reduce lipid oxidation and off-odor volatiles of irradiated pork homogenates and patties. Meat Science, 63(1), 1-8.

Orczewska-Dudek, S., Bederska-Łojewska, D., Pieszka, M., \& Pietras, M. (2012). Cholesterol and Lipid Peroxides in Animal Products and Health Implications - A Review. Annals of Animal Science, 12(1), 25-52.

Osada, K., Hoshina, S., Nakamura, S., \& Sugano, M. (2000). Cholesterol oxidation in meat products and its regulation by supplementation of sodium nitrite and apple polyphenol before processing. Journal of Agricultural and Food Chemistry, 48(9), 3823-9.

Ough, S. C., \& Were, L. (2005). Sulfur Dioxide and Sulfites. In P. M. Davidson, J. N. Sofos, \& A. L. Branen (Eds.), Antimicrobials in food (3rd ed., pp. 143-169). Boca Ratón, FL: Taylor $\&$ Francis.

Perenlei, G., Tojo, H., Okada, T., Kubota, M., Kadowaki, M., \& Fujimura, S. (2014). Effect of dietary astaxanthin rich yeast, Phaffia rhodozyma, on meat quality of broiler chickens. Animal Science Journal, 85(10), 895-903.

Poli, G., Biasi, F., \& Leonarduzzi, G. (2013). Oxysterols in the pathogenesis of major chronic diseases. Redox Biology, 1(1), 125-130.

Razzazi-Fazeli, E., Kleineisen, S., \& Luf, W. (2000). Determination of cholesterol oxides in processed food using high-performance liquid chromatography-mass spectrometry with atmospheric pressure chemical ionisation. Journal of Chromatography. A, 896(1-2), 321-34.

Resconi, V. C., Campo, M. M., Montossi, F., Ferreira, V., Sañudo, C., \& Escudero, A. (2010). Relationship between odour-active compounds and flavour perception in meat from lambs fed different diets. Meat Science, 85(4), 700-706. 
Rodríguez, A., Losada, V., Larraín, M. A., Quitral, V., Vinagre, J., \& Aubourg, S. P. (2007). Development of Lipid Changes Related to Quality Loss During the Frozen Storage of Farmed Coho Salmon (Oncorhynchus kisutch). Journal of the American Oil Chemists' Society, 84(8), 727-734.

Sánchez-Escalante, A., Djenane, D., Torrescano, G., Beltrán, J. A., \& Roncalés, P. (2001). The effects of ascorbic acid, taurine, carnosine and rosemary powder on colour and lipid stability of beef patties packaged in modified atmosphere. Meat Science, 58(4), 421-9.

SANCO. (2017). Database on Food Additives, Application version 3.21. Directorate General of Health and Food Safety. Bruxelles.

Santos, A., Giráldez, F. J., Mateo, J., Frutos, J., \& Andrés, S. (2018). Programming Merino lambs by early feed restriction reduces growth rates and increases fat accretion during the fattening period with no effect on meat quality traits. Meat Science, 135, 20-26.

Savage, G. P., Dutta, P. C., \& Rodriguez-Estrada, M. T. (2002). Cholesterol oxides: their occurrence and methods to prevent their generation in foods. Asia Pacific Journal of Clinical Nutrition, 11(1), 72-78.

Serpen, A., Gökmen, V., \& Fogliano, V. (2012). Total antioxidant capacities of raw and cooked meats. Meat Science, 90(1), 60-65.

Shah, M. A., Bosco, S. J. D., \& Mir, S. A. (2014). Plant extracts as natural antioxidants in meat and meat products. Meat Science, 98(1), 21-33.

Skibsted, L. H. (2012). Carotenoids in Antioxidant Networks. Colorants or Radical Scavengers. Journal of Agricultural and Food Chemistry, 60(10), 2409-2417.

Varvara, M., Bozzo, G., Disanto, C., Pagliarone, C. N., Celano, G. V., \& Celano, G. V. (2016). The use of the ascorbic acid as food additive and technical-legal issues. Italian Journal of Food Safety, 5(1), 4313.

Vieira, C., Fernández-Diez, A., Mateo, J., Bodas, R., Soto, S., \& Manso, T. (2012). Effects of addition of different vegetable oils to lactating dairy ewes' diet on meat quality characteristics of suckling lambs reared on the ewes' milk. Meat Science, 91(3), 277-283.

Yang, Z., Xie, J., Zhang, L., Du, R., Cao, C, Wang, M, Acree, T., \& Suna, B. (2015) Aromatic effect of fat and oxidized fat on a meat-like model reaction system of cysteine and glucose. Flavour and Fragance Journal, 30, 320-329. 
Table 1. Analysis carried out in three batches of raw refrigerated, raw frozen, cooked and reheated patties and the patty storage duration before analysis

\section{Oxidative status analysis}

Storage day

\begin{tabular}{lll}
\hline Raw refrigerated (three patties) & TBARS, color, $\mathrm{pH}$ and redox potential & 0,5 and $11^{\mathrm{a}}$ \\
Raw frozen (one patty) & TBARS & $90^{\mathrm{a}}$ \\
Cooked (after five days of refrigerated & TBARS & 0,2 and $4^{\mathrm{b}}$ \\
storage; three quarter patty) & Cholesterol oxides and volatile & $0^{\mathrm{b}}$ \\
& compounds &
\end{tabular}

Cooked and microwave reheated after Cholesterol oxides

$2^{\mathrm{b}}$

two days of refrigerated storage (one

quarter patty)

a Day of sampling after the elaboration of patties during refrigerated storage
b Day of sampling after the cooking of the patty 
Table 2. Effect of different antioxidant treatments on selected quality traits of raw lamb patties stored at refrigeration temperature under aerobic packaging conditions

\begin{tabular}{|c|c|c|c|c|c|c|c|c|c|c|c|c|c|c|c|}
\hline & \multicolumn{7}{|c|}{ Antioxidant treatment (treat) } & \multicolumn{3}{|c|}{ Storage day (day) } & \multicolumn{2}{|c|}{ RSD } & \multicolumn{3}{|c|}{ Significance } \\
\hline & $\mathrm{CON}$ & SULP & $\mathrm{ASC}$ & AST20 & AST40 & AST60 & AST80 & 0 & 5 & 11 & Treat & Day & Treat & Day & $\begin{array}{c}\text { Treat } \mathrm{x} \\
\text { Day }\end{array}$ \\
\hline $\mathrm{pH}$ & $5.62^{\mathrm{ab}}$ & $5.64^{\mathrm{ab}}$ & $5.68^{\mathrm{a}}$ & $5.62^{\mathrm{ab}}$ & $5.60^{b}$ & $5.59^{b}$ & $5.58^{b}$ & $5.62^{\mathrm{ab}}$ & $5.57^{b}$ & $5.66^{\mathrm{a}}$ & 0.047 & 0.045 & $* *$ & $* * *$ & NS \\
\hline Eh & 92.83 & 70.50 & 29.28 & 71.89 & 72.72 & 71.72 & 71.11 & $49.21^{\mathrm{b}}$ & $88.62^{\mathrm{a}}$ & $67.9^{\mathrm{ab}}$ & 49.39 & 17.68 & NS & $* *$ & NS \\
\hline TBARS & $8.35^{\mathrm{a}}$ & $7.98^{\mathrm{ab}}$ & $7.85^{\mathrm{ab}}$ & $6.55^{\mathrm{abc}}$ & $6.10^{\mathrm{abc}}$ & $5.43^{\mathrm{bc}}$ & $4.89^{c}$ & $1.39^{c}$ & $7.80^{\mathrm{b}}$ & $11.01^{\mathrm{a}}$ & 1.64 & 1.10 & $* *$ & $* * *$ & $* * *$ \\
\hline Color & & & & & & & & & & & & & & & \\
\hline$L^{*}$ & $49.92^{\mathrm{a}}$ & $47.53^{\mathrm{ab}}$ & $47.99^{\mathrm{ab}}$ & $44.61^{\mathrm{bc}}$ & $41.78^{\mathrm{cd}}$ & $40.76^{\mathrm{cd}}$ & $38.69^{d}$ & 45.04 & 43.76 & 44.61 & 2.78 & 1.75 & $* * *$ & + & NS \\
\hline$a^{*}$ & $3.85^{\mathrm{d}}$ & $5.19^{\mathrm{d}}$ & $6.24^{\mathrm{d}}$ & $14.02^{\mathrm{c}}$ & $17.99^{\mathrm{b}}$ & $22.17^{\mathrm{a}}$ & $24.12^{\mathrm{a}}$ & $14.21^{\mathrm{a}}$ & $13.7^{\mathrm{a}}$ & $12.2^{\mathrm{b}}$ & 1.80 & 0.69 & $* * *$ & $* * *$ & NS \\
\hline$b^{*}$ & $13.91^{\mathrm{c}}$ & $13.04^{\mathrm{c}}$ & $14.75^{\mathrm{bc}}$ & $18.46^{\mathrm{ab}}$ & $19.24^{\mathrm{a}}$ & $21.47^{\mathrm{a}}$ & $22.10^{\mathrm{a}}$ & $18.16^{\mathrm{a}}$ & $17.41^{\mathrm{ab}}$ & $17.13^{b}$ & 2.47 & 1.27 & $* * *$ & $*$ & NS \\
\hline
\end{tabular}

\# : CON = control (no antioxidant additives); SULP = $450 \mathrm{mg}$ sodium metabisulphite per kg of patty mixture; ASC $=500 \mathrm{mg}$ sodium ascorbate per kg of patty mixture; AST2 $=20 \mathrm{mg}$ of astaxanthin per $\mathrm{kg}$ of patty mixture; AST40 $=40 \mathrm{mg}$ of astaxanthin per $\mathrm{kg}$ of patty mixture; AST60 = $60 \mathrm{mg}$ of astaxanthin per $\mathrm{kg}$ of patty mixture; AST $80=80 \mathrm{mg}$ of astaxanthin per kg of patty mixture.

$\mathrm{RSD}=$ residual standard deviation .

Significance: NS = not significant $+=P<0.1 ; *=P<0.05 ; * *=P<0.01 ; * * *=P<0.001$.

TBARS $=$ thiobarbituric acid-reactive substances (expressed as $\mathrm{mg}$ of malondialdehyde per $\mathrm{kg}$ of patty).

abcd $=$ different superscripts in the same row indicate statistical differences by the Tukey-Kramer test $(P<0.05)$ for antioxidant treatment and by the Bonferroni test $(P<0.05)$ for storage day. 
Table 3. Effect of different antioxidant treatments on thiobarbituric acid-reactive substances (TBARS; expressed as mg of malondialdehyde per kg of meat) of cooked lamb patties stored at refrigeration temperature under aerobic packaging conditions

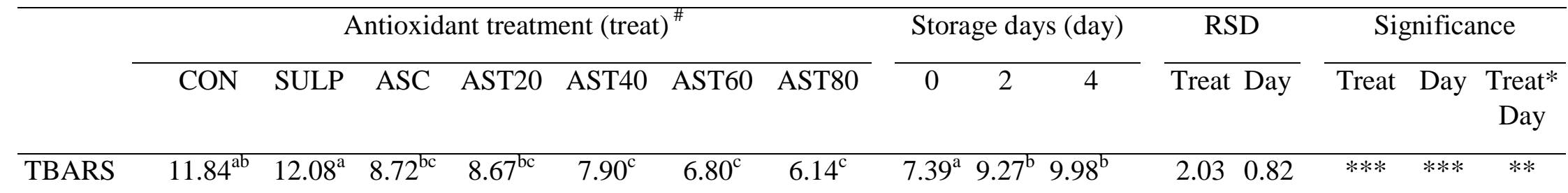

\#: $\mathrm{CON}=$ control (no antioxidant additives); SULP $=450 \mathrm{mg}$ sodium metabisulphite per kg of patty mixture; ASC $=500 \mathrm{mg}$ sodium ascorbate per kg of patty mixture; AST20 $=20 \mathrm{mg}$ of astaxanthin per $\mathrm{kg}$ of patty mixture; AST40 $=40 \mathrm{mg}$ of astaxanthin per $\mathrm{kg}$ of patty mixture; AST60 = $60 \mathrm{mg}$ of astaxanthin per $\mathrm{kg}$ of patty mixture; AST $80=80 \mathrm{mg}$ of astaxanthin per $\mathrm{kg}$ of patty mixture.

$\mathrm{RSD}=$ residual standard deviation.

Significance: $* *=P<0.01 ; * * *=P<0.001$.

abc: different superscripts in the same row indicate statistical differences by the Tukey-Kramer test $(P<0.05)$ for antioxidant treatment and by the Bonferroni test $(P<0.05)$ for storage day. 
Table 4. Effect of different antioxidant treatments on oxysterols content ( $\mu \mathrm{g}$ per $\mathrm{g}$ of meat) in cooked and microwave-reheated lamb patties

\begin{tabular}{|c|c|c|c|c|c|c|c|c|c|}
\hline & \multicolumn{7}{|c|}{ Antioxidant treatment ${ }^{\#}$} & \multirow[t]{2}{*}{ RSD } & \multirow[t]{2}{*}{ Significance $^{\mathrm{I}}$} \\
\hline & $\mathrm{CON}$ & SULP & ASC & AST20 & AST40 & AST60 & AST80 & & \\
\hline \multicolumn{10}{|l|}{$7 \alpha-\mathrm{HC}$} \\
\hline Cooked & $3.64^{\mathrm{ab}}$ & $5.19^{\mathrm{a}}$ & $2.21^{\mathrm{b}}$ & $2.99^{\mathrm{ab}}$ & $2.40^{\mathrm{b}}$ & $2.32^{\mathrm{b}}$ & $1.92^{\mathrm{b}}$ & 0.589 & $* *$ \\
\hline Microwave-reheated & $5.59^{\mathrm{ab}}$ & $8.94^{\mathrm{a}}$ & $3.11^{\mathrm{b}}$ & $3.29^{\mathrm{b}}$ & $2.79^{\mathrm{b}}$ & $2.81^{\mathrm{b}}$ & $2.25^{\mathrm{b}}$ & 1.110 & $* *$ \\
\hline$S E$ & 0.255 & 0.460 & 1.035 & 0.225 & 0.360 & 0.205 & 0.250 & & \\
\hline Significance $^{2}$ & + & + & NS & NS & NS & NS & NS & & \\
\hline \multicolumn{10}{|l|}{$7 \beta-\mathrm{HC}$} \\
\hline Cooked & 4.15 & 3.17 & 3.74 & 3.45 & 2.75 & 2.89 & 2.72 & 0.497 & NS \\
\hline Microwave-reheated & $6.33^{\mathrm{a}}$ & $4.53^{\mathrm{ab}}$ & $4.52^{\mathrm{ab}}$ & $4.09^{\mathrm{ab}}$ & $3.70^{\mathrm{ab}}$ & $3.45^{\mathrm{ab}}$ & $2.89^{\mathrm{b}}$ & 0.814 & $*$ \\
\hline$S E$ & 0.355 & 0.245 & 0.775 & 0.160 & 0.340 & 0.045 & 0.020 & & \\
\hline Significance $^{2}$ & NS & NS & NS & NS & NS & + & + & & \\
\hline \multicolumn{10}{|l|}{$\beta-\mathrm{CE}$} \\
\hline Cooked & 4.36 & 4.01 & 3.34 & 2.77 & 2.71 & 2.85 & 3.16 & 1.069 & NS \\
\hline Microwave-reheated & 7.15 & 5.56 & 5.69 & 3.98 & 3.52 & 3.36 & 3.85 & 1.516 & NS \\
\hline$S E$ & 0.310 & 0.505 & 0.980 & 0.755 & 0.575 & 0.800 & 1.290 & & \\
\hline Significance $^{2}$ & + & NS & NS & $*$ & NS & NS & NS & & \\
\hline
\end{tabular}


$\alpha-\mathrm{CE}$

$\begin{array}{rccccccccc}\text { Cooked } & 0.96^{\mathrm{a}} & 0.74^{\mathrm{ab}} & 0.71^{\mathrm{ab}} & 0.72^{\mathrm{ab}} & 0.60^{\mathrm{b}} & 0.59^{\mathrm{b}} & 0.54^{\mathrm{b}} & 0.084 & * \\ \text { Microwave-reheated } & 1.30 & 0.72 & 1.28 & 0.66 & 0.61 & 0.74 & 0.59 & 0.384 & \text { NS } \\ \text { SE } & 0.205 & 0.010 & 0.710 & 0.100 & 0.130 & 0.055 & 0.230 & & \\ \text { Significance }^{2} & \text { NS } & \text { NS } & \text { NS } & \text { NS } & \text { NS } & \text { NS } & \text { NS } & & \end{array}$

CDO

$\begin{array}{rccccccccc}\text { Cooked } & 0.61 & 0.35 & 0.27 & 0.64 & 0.36 & 0.32 & 0.33 & 0.172 & \text { NS } \\ \text { Microwave-reheated } & 0.61 & 0.27 & 0.42 & 0.38 & 0.33 & 0.41 & 0.24 & 0.128 & \text { NS } \\ \text { SE } & 0.360 & 0.0350 & 0.265 & 0.070 & 0.0350 & 0.140 & 0.135 & & \\ \text { Significance }^{2} & \text { NS } & \text { NS } & \text { NS } & \text { NS } & \text { NS } & \text { NS } & \text { NS } & & \end{array}$

7-KC

$\begin{array}{rccccccccc}\text { Cooked } & 9.94^{\mathrm{a}} & 3.47^{\mathrm{b}} & 5.96^{\mathrm{b}} & 6.88^{\mathrm{ab}} & 5.62^{\mathrm{b}} & 5.68^{\mathrm{b}} & 5.39^{\mathrm{b}} & 0.953 & * * \\ \text { Microwave-reheated } & 15.89^{\mathrm{a}} & 4.63^{\mathrm{b}} & 8.44^{\mathrm{ab}} & 8.31^{\mathrm{ab}} & 7.33^{\mathrm{b}} & 7.29^{\mathrm{b}} & 5.99^{\mathrm{b}} & 1.961 & * \\ S E & 0.305 & 0.165 & 3.260 & 1.665 & 1.520 & 0.275 & 1.385 & & \\ \text { Significance }^{2} & * & + & \text { NS } & \text { NS } & \text { NS } & \text { NS } & \text { NS } & \end{array}$

$\sum$ COPs

$\begin{array}{rccccccccc}\text { Cooked } & 23.66 & 16.94 & 16.24 & 17.45 & 14.44 & 14.67 & 14.07 & 2.790 & \text { NS } \\ \text { Microwave-reheated } & 36.88 & 24.65 & 23.48 & 20.72 & 18.3 & 18.06 & 15.81 & 5.463 & + \\ \text { SE } & 0.065 & 0.070 & 7.030 & 2.970 & 2.965 & 1.430 & 3.305 & & \\ \text { Significance }^{2} & * * & * * & \text { NS } & \text { NS } & \text { NS } & \text { NS } & \text { NS } & & \end{array}$


\# $:$ CON $=$ control (no antioxidant additives); SULP $=450 \mathrm{mg}$ sodium metabisulphite per kg of patty mixture; ASC $=500 \mathrm{mg}$ sodium ascorbate per kg of patty mixture; AST20 $=20 \mathrm{mg}$ of astaxanthin per $\mathrm{kg}$ of patty mixture; AST40 $=40 \mathrm{mg}$ of astaxanthin per $\mathrm{kg}$ of patty mixture; AST60 $=60 \mathrm{mg}$ of astaxanthin per kg of patty mixture; AST $80=80 \mathrm{mg}$ of astaxanthin per kg of patty mixture.

$7 \alpha-\mathrm{HC}=7 \mathrm{a}$-hydroxycholesterol; $7 \beta-\mathrm{HC}=7 \beta$-hydroxycholesterol; $\alpha$-CE $=5,6$ - $\alpha$-epoxycholesterol; $\beta$-CE = 5,6- $\beta$-epoxycholesterol; $\mathrm{CDO}=$ cholestan-3,5-dien-7one (expressed as mg of $\alpha$-CE equivalents per $\mathrm{g}$ of meat); 7-KC $=7$-ketocholesterol; $\sum \mathrm{COPs}=$ sum of cholesterol oxidation products.

RSD = residual standard deviation.

$\mathrm{SE}=$ standard error

Significance $^{1}$ (Between antioxidant treatments); Significance ${ }^{2}$ (Between heating treatment): NS $=$ not significant; $+=P<0.1 ; *=P<0.05 ; * *=P<0.01 ; * * *=P$ $<0.001$.

${ }^{\mathrm{abc}}$ : different superscripts in the same row indicate statistical differences in antioxidant treatment by the Tukey-Kramer test $(P<0.05)$. 
Table 5. Effect of different antioxidant treatments on volatile compounds (ng equivalent of hexanal per ml of headspace) of cooked lamb patties

\begin{tabular}{|c|c|c|c|c|c|c|c|c|c|c|}
\hline & \multirow[t]{2}{*}{ LRI } & \multicolumn{7}{|c|}{ Antioxidant treatment } & \multirow[t]{2}{*}{ RSD } & \multirow[t]{2}{*}{ Significance } \\
\hline & & $\mathrm{CON}$ & SULP & ASC & AST20 & AST40 & AST60 & AST80 & & \\
\hline \multicolumn{11}{|c|}{ Aliphatic hydrocarbons } \\
\hline Octane & 800 & $3.93^{\mathrm{a}}$ & $2.66^{\mathrm{abc}}$ & $3.09^{\mathrm{ab}}$ & $2.52^{\mathrm{abc}}$ & $1.57^{\mathrm{bc}}$ & $1.67^{\mathrm{bc}}$ & $1.18^{\mathrm{c}}$ & 0.659 & $* *$ \\
\hline Tridecane & 1300 & $2.25^{\mathrm{a}}$ & $1.48^{\mathrm{abc}}$ & $2.01^{\mathrm{ab}}$ & $1.49^{\mathrm{abc}}$ & $1.29^{\mathrm{bc}}$ & $1.17^{\mathrm{bc}}$ & $0.81^{\mathrm{c}}$ & 0.339 & $* *$ \\
\hline Tetradecane & 1400 & $1.37^{\mathrm{ab}}$ & $1.16^{\mathrm{ab}}$ & $1.47^{\mathrm{a}}$ & $1.07^{\mathrm{ab}}$ & $1.04^{\mathrm{ab}}$ & $0.95^{\mathrm{ab}}$ & $1.38^{\mathrm{b}}$ & 0.237 & $*$ \\
\hline 1-Pentadecene & 1487 & 0.49 & 0.72 & 0.67 & 0.64 & 0.66 & 0.55 & 0.42 & 0.144 & NS \\
\hline Pentadecane & 1492 & 2.17 & 1.89 & 2.16 & 1.86 & 1.73 & 1.55 & 1.28 & 0.330 & + \\
\hline Subtotal & & $12.08^{\mathrm{a}}$ & $9.21^{\mathrm{ab}}$ & $9.90^{\mathrm{ab}}$ & $8.83^{\mathrm{ab}}$ & $7.16^{\mathrm{ab}}$ & $6.64^{\mathrm{ab}}$ & $4.84^{b}$ & 2.074 & $*$ \\
\hline \multicolumn{11}{|c|}{$\underline{\text { Aliphatic aldehydes }}$} \\
\hline Hexanal & 806 & $165.67^{\mathrm{ab}}$ & $172.97^{\mathrm{a}}$ & $136.66^{\mathrm{abc}}$ & $123.66^{\mathrm{abc}}$ & $121.84^{\mathrm{abc}}$ & $94.63^{b c}$ & $71.99^{c}$ & 25.64 & $* *$ \\
\hline Heptanal & 904 & $21.26^{\mathrm{a}}$ & $20.49^{\mathrm{a}}$ & $18.96^{\mathrm{ab}}$ & $13.99^{\mathrm{abc}}$ & $11.97^{\mathrm{bc}}$ & $10.33^{c}$ & $7.30^{c}$ & 2.987 & $* * *$ \\
\hline Octanal & 1001 & $16.77^{\mathrm{a}}$ & $15.06^{\mathrm{a}}$ & $14.92^{\mathrm{a}}$ & $10.14^{\mathrm{ab}}$ & $7.84^{\mathrm{b}}$ & $6.94^{\mathrm{b}}$ & $4.81^{\mathrm{b}}$ & 2.450 & $* * *$ \\
\hline 2-Octenal & 1057 & $2.79^{a}$ & $2.54^{\mathrm{ab}}$ & $2.24^{\mathrm{abc}}$ & $1.73^{\mathrm{abcd}}$ & $1.62^{\mathrm{bcd}}$ & $1.29^{\mathrm{cd}}$ & $0.93^{\mathrm{d}}$ & 0.386 & $* * *$ \\
\hline Nonanal & 1101 & $25.26^{\mathrm{a}}$ & $25.93^{\mathrm{a}}$ & $22.45^{\mathrm{ab}}$ & $17.77^{\mathrm{abc}}$ & $15.05^{\mathrm{bc}}$ & $13.36^{\mathrm{c}}$ & $10.20^{\mathrm{c}}$ & 3.067 & $* * *$ \\
\hline 2-Nonenal & 1158 & $2.23^{\mathrm{a}}$ & $1.12^{\mathrm{ab}}$ & $1.58^{\mathrm{ab}}$ & $1.13^{\mathrm{ab}}$ & $0.83^{\mathrm{ab}}$ & $0.86^{\mathrm{ab}}$ & $0.62^{\mathrm{b}}$ & 0.547 & $*$ \\
\hline 2-Decenal & 1260 & $3.27^{\mathrm{a}}$ & $2.30^{\mathrm{ab}}$ & $2.04^{\mathrm{ab}}$ & $1.03^{\mathrm{bc}}$ & $0.54^{\mathrm{bc}}$ & $0.54^{\mathrm{bc}}$ & $0.14^{\mathrm{c}}$ & 0.659 & $* * *$ \\
\hline
\end{tabular}




\begin{tabular}{|c|c|c|c|c|c|c|c|c|c|c|}
\hline 2,4-Decadienal & 1323 & $2.53^{\mathrm{a}}$ & $2.12^{\mathrm{ab}}$ & $1.99^{\mathrm{abc}}$ & $1.27^{\mathrm{abc}}$ & $1.12^{\mathrm{bc}}$ & $1.03^{\mathrm{bc}}$ & $0.77^{\mathrm{c}}$ & 0.457 & $* *$ \\
\hline 2-Undecenal & 1370 & $4.11^{\mathrm{a}}$ & $3.06^{\mathrm{ab}}$ & $2.91^{\mathrm{ab}}$ & $1.55^{\mathrm{bc}}$ & $0.93^{\mathrm{bc}}$ & $0.89^{\mathrm{bc}}$ & $0.50^{\mathrm{c}}$ & 0.857 & $* *$ \\
\hline Dodecanal & 1409 & $2.02^{\mathrm{ab}}$ & $2.24^{\mathrm{a}}$ & $1.88^{\mathrm{ab}}$ & $1.71^{\mathrm{ab}}$ & $1.80^{\mathrm{ab}}$ & $1.42^{\mathrm{ab}}$ & $1.25^{\mathrm{b}}$ & 0.346 & $*$ \\
\hline Tridecanal & 1514 & $2.12^{\mathrm{ab}}$ & $2.31^{\mathrm{a}}$ & $2.24^{\mathrm{a}}$ & $1.90^{\mathrm{ab}}$ & $1.54^{\mathrm{ab}}$ & $1.40^{\mathrm{ab}}$ & $1.09^{\mathrm{b}}$ & 0.403 & $* *$ \\
\hline Tetradecanal & 1625 & $5.99^{\mathrm{ab}}$ & $8.03^{\mathrm{a}}$ & $5.73^{\mathrm{ab}}$ & $5.66^{\mathrm{ab}}$ & $4.28^{\mathrm{b}}$ & $3.86^{\mathrm{b}}$ & $2.94^{\mathrm{b}}$ & 1.234 & $* *$ \\
\hline Pentadecanal & 1720 & $8.72^{\mathrm{ab}}$ & $12.01^{\mathrm{a}}$ & $10.18^{\mathrm{ab}}$ & $10.08^{\mathrm{ab}}$ & $8.11^{\mathrm{ab}}$ & $7.51^{\mathrm{ab}}$ & $6.23^{\mathrm{b}}$ & 1.994 & $*$ \\
\hline 14-Methylpentadecanal & 1783 & 1.28 & 1.54 & 1.32 & 1.46 & 1.06 & 0.998 & 0.84 & 0.375 & NS \\
\hline Hexadecanal & 1821 & 56.40 & 73.53 & 70.40 & 80.21 & 67.32 & 64.04 & 59.40 & 14.35 & NS \\
\hline 14-Methylhexadecanal & 1890 & 1.72 & 2.19 & 1.98 & 2.18 & 1.65 & 1.48 & 1.45 & 0.383 & NS \\
\hline 15-Methylhexadecanal & 1894 & 1.81 & 2.21 & 2.13 & 2.41 & 1.93 & 1.71 & 1.72 & 0.492 & NS \\
\hline Heptadecanal & 1922 & 1.96 & 2.31 & 2.17 & 2.40 & 1.88 & 1.53 & 1.58 & 0.437 & NS \\
\hline (E)-9-Octadecenal & 2005 & 2.60 & 3.14 & 3.44 & 3.72 & 2.87 & 2.36 & 2.57 & 0.781 & NS \\
\hline (Z)-9-Octadecenal & 2010 & 2.18 & 2.53 & 2.91 & 3.15 & 2.32 & 1.84 & 2.04 & 0.783 & NS \\
\hline Octadecanal & 2028 & 3.99 & 4.27 & 5.28 & 5.20 & 4.30 & 3.39 & 3.76 & 1.311 & NS \\
\hline Subtotal & & $338.63^{\mathrm{ab}}$ & $366.32^{\mathrm{a}}$ & $316.99^{\mathrm{ab}}$ & $295.36^{\mathrm{abc}}$ & $263.23^{\mathrm{abc}}$ & $223.99^{\mathrm{bc}}$ & $184.17^{\mathrm{c}}$ & 45.53 & $* *$ \\
\hline \multicolumn{11}{|l|}{$\underline{\text { Aliphatic ketones }}$} \\
\hline 2-Heptanone & 892 & $8.24^{\mathrm{a}}$ & $5.93^{\mathrm{abc}}$ & $7.16^{\mathrm{ab}}$ & $6.71^{\mathrm{abc}}$ & $5.89^{\mathrm{abc}}$ & $4.38^{\mathrm{bc}}$ & $3.52^{\mathrm{c}}$ & 1.190 & $* *$ \\
\hline 2,3-Octanodione & 982 & $6.00^{\mathrm{a}}$ & $3.80^{\mathrm{abc}}$ & $4.26^{\mathrm{abc}}$ & $5.47^{\mathrm{abc}}$ & $5.67^{\mathrm{ab}}$ & $3.70^{\mathrm{bc}}$ & $3.31^{\mathrm{c}}$ & 0.806 & $* *$ \\
\hline 2-Pentadecanone & 1702 & $2.38^{\mathrm{a}}$ & $2.31^{\mathrm{ab}}$ & $2.17^{\mathrm{ab}}$ & $2.42^{\mathrm{a}}$ & $1.94^{\mathrm{ab}}$ & $1.88^{\mathrm{ab}}$ & $1.66^{\mathrm{b}}$ & 0.253 & $*$ \\
\hline
\end{tabular}




\begin{tabular}{lccccccccccc}
\hline 2-Heptadecanone & 1903 & $2.16^{\mathrm{ab}}$ & $2.37^{\mathrm{a}}$ & $2.23^{\mathrm{ab}}$ & $2.33^{\mathrm{ab}}$ & $1.87^{\mathrm{ab}}$ & $1.62^{\mathrm{b}}$ & $1.67^{\mathrm{ab}}$ & 0.261 & $*$ & \\
Subtotal & & $19.45^{\mathrm{a}}$ & $14.91^{\mathrm{abc}}$ & $16.71^{\mathrm{ab}}$ & $17.40^{\mathrm{ab}}$ & $16.04^{\mathrm{ab}}$ & $12.09^{\mathrm{bc}}$ & $10.32^{\mathrm{c}}$ & 2.025 & $* *$ &
\end{tabular}

$\underline{\text { Aliphatic alcohols }}$

\begin{tabular}{|c|c|c|c|c|c|c|c|c|c|c|}
\hline Pentanol & 773 & 12.72 & 8.34 & 10.95 & 7.44 & 7.62 & 6.44 & 4.10 & 3.189 & + \\
\hline Hexanol & 872 & 4.38 & 2.53 & 3.78 & 3.10 & 2.31 & 2.70 & 2.10 & 1.182 & NS \\
\hline Heptanol & 969 & $3.43^{\mathrm{a}}$ & $2.63^{\mathrm{ab}}$ & $2.80^{\mathrm{ab}}$ & $1.96^{\mathrm{abc}}$ & $1.35^{\mathrm{bc}}$ & $1.05^{\mathrm{c}}$ & $0.77^{\mathrm{c}}$ & 0.550 & $* * *$ \\
\hline 1-Octen-3-ol & 978 & $14.88^{\mathrm{a}}$ & $12.40^{\mathrm{ab}}$ & $12.74^{\mathrm{ab}}$ & $12.05^{\mathrm{abc}}$ & $10.62^{\mathrm{abc}}$ & $8.30^{\mathrm{bc}}$ & $5.87^{\mathrm{c}}$ & 2.242 & $* *$ \\
\hline 2-Ethyl-1-hexanol & 1026 & $4.93^{\mathrm{c}}$ & $6.33^{\mathrm{bc}}$ & $9.57^{\mathrm{a}}$ & $6.53^{\mathrm{bc}}$ & $7.77^{\mathrm{abc}}$ & $6.83^{\mathrm{abc}}$ & $8.11^{\mathrm{ab}}$ & 1.091 & $* *$ \\
\hline 2-Octen-1-ol & 1065 & $2.12^{\mathrm{a}}$ & $1.72^{\mathrm{ab}}$ & $1.87^{\mathrm{a}}$ & $1.67^{\mathrm{ab}}$ & $1.58^{\mathrm{ab}}$ & $1.25^{\mathrm{ab}}$ & $0.84^{\mathrm{b}}$ & 0.362 & $*$ \\
\hline Octanol & 1068 & $4.52^{\mathrm{a}}$ & $3.85^{\mathrm{ab}}$ & $4.33^{\mathrm{a}}$ & $2.95^{\mathrm{abc}}$ & $2.58^{\mathrm{bc}}$ & $2.16^{\mathrm{c}}$ & $1.62^{\mathrm{c}}$ & 0.565 & $* * *$ \\
\hline Dodecanol & 1476 & 18.48 & 22.16 & 20.25 & 17.51 & 23.90 & 16.94 & 15.40 & 4.738 & NS \\
\hline Subtotal & & $68.23^{\mathrm{a}}$ & $62.44^{\mathrm{ab}}$ & $68.17^{\mathrm{a}}$ & $55.10^{\mathrm{abc}}$ & $58.61^{\mathrm{abc}}$ & $46.44^{\mathrm{bc}}$ & $39.36^{\mathrm{c}}$ & 7.484 & $* *$ \\
\hline \multicolumn{11}{|l|}{$\underline{\text { Furans }}$} \\
\hline 2-Pentylfuran & 988 & $92.12^{\mathrm{a}}$ & $75.65^{\mathrm{ab}}$ & $72.24^{\mathrm{abc}}$ & $70.88^{\mathrm{abc}}$ & $64.72^{\mathrm{abc}}$ & $50.28^{\mathrm{bc}}$ & $41.60^{\mathrm{c}}$ & 11.88 & $* *$ \\
\hline (E)-2-Pentenylfuran & 997 & $4.04^{\mathrm{a}}$ & $3.60^{\mathrm{ab}}$ & $3.71^{\mathrm{ab}}$ & $2.85^{\mathrm{abc}}$ & $2.47^{\mathrm{abc}}$ & $1.86^{\mathrm{bc}}$ & $1.40^{\mathrm{c}}$ & 0.689 & $* *$ \\
\hline 2-Hexylfuran & 1087 & $3.58^{\mathrm{a}}$ & $3.46^{\mathrm{a}}$ & $5.08^{\mathrm{b}}$ & $3.37^{\mathrm{a}}$ & $3.55^{\mathrm{a}}$ & $3.04^{\mathrm{a}}$ & $2.67^{\mathrm{a}}$ & 0.480 & $* *$ \\
\hline 2-Octylfuran & 1289 & $3.96^{\mathrm{a}}$ & $3.68^{\mathrm{ab}}$ & $3.26^{\mathrm{abc}}$ & $2.70^{\mathrm{abc}}$ & $2.17^{\mathrm{abc}}$ & $1.76^{\mathrm{bc}}$ & $1.38^{\mathrm{c}}$ & 0.786 & $* *$ \\
\hline Subtotal & & $105.45^{\mathrm{a}}$ & $87.51^{\mathrm{ab}}$ & $85.47^{\mathrm{ab}}$ & $80.75^{\mathrm{abc}}$ & $73.69^{\mathrm{abc}}$ & $57.52^{\mathrm{bc}}$ & $47.46^{\mathrm{c}}$ & 13.34 & $* *$ \\
\hline
\end{tabular}


$\underline{\text { Sulfur compounds }}$

Dimethyl disulfide

Dimethyl sulfide

Subtotal

\section{Benzene compounds}

\begin{tabular}{|c|c|c|c|c|c|c|c|c|c|c|}
\hline Benzaldehyde & 966 & 7.64 & 7.38 & 8.65 & 8.18 & 9.77 & 9.75 & 8.59 & 1.682 & NS \\
\hline Benzeneacetaldehyde & 1046 & 2.83 & 2.31 & 2.81 & 2.76 & 2.89 & 2.81 & 2.50 & 0.556 & NS \\
\hline $\begin{array}{l}\text { 1-Phenyl-1,3,3- } \\
\text { trimethylindane }\end{array}$ & 1738 & 0.90 & 1.41 & 1.64 & 1.50 & 1.81 & 1.42 & 1.35 & 0.560 & NS \\
\hline Diphenyl ethanedione & 1856 & 1.57 & 0.78 & 0.65 & 1.01 & 1.32 & 1.14 & 0.67 & 1.033 & NS \\
\hline Benzil dimethyl ketal & 1912 & 14.72 & 7.71 & 5.07 & 7.51 & 6.22 & 6.32 & 4.93 & 7.231 & NS \\
\hline Subtotal & & 30.01 & 23.04 & 21.52 & 23.67 & 25.12 & 25.05 & 21.56 & 9.293 & NS \\
\hline Total sum of volatiles & & $583.22^{\mathrm{a}}$ & $574.95^{\mathrm{a}}$ & $527.53^{\mathrm{a}}$ & $489.86^{\mathrm{ab}}$ & $453.83^{\mathrm{ab}}$ & $381.60^{\mathrm{ab}}$ & $317.15^{\mathrm{b}}$ & 73.34 & $* *$ \\
\hline
\end{tabular}




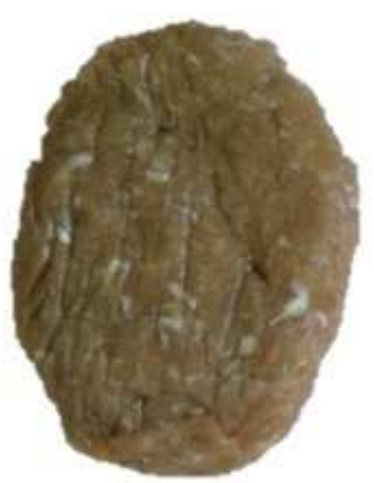

CON

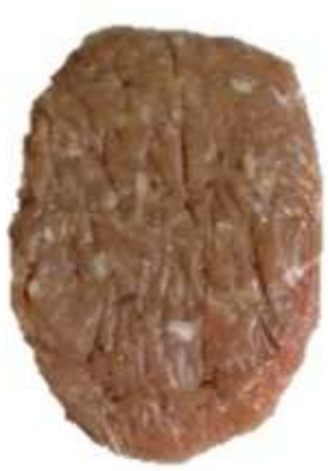

SULP

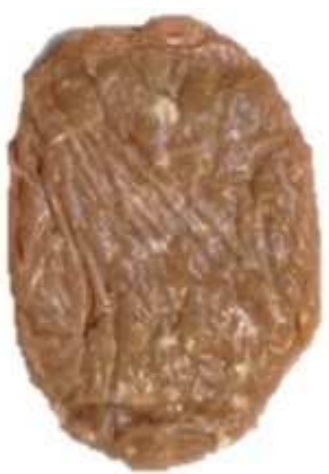

ASC

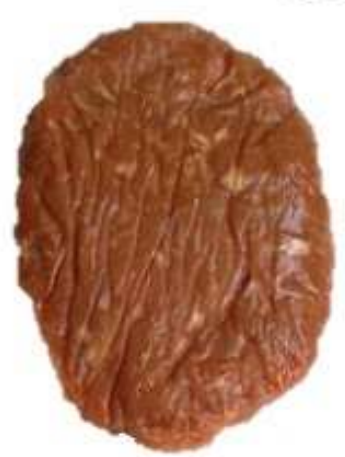

AST20

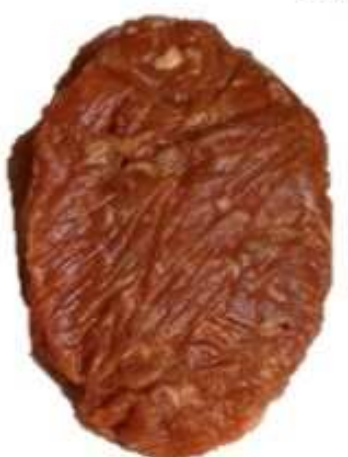

AST40

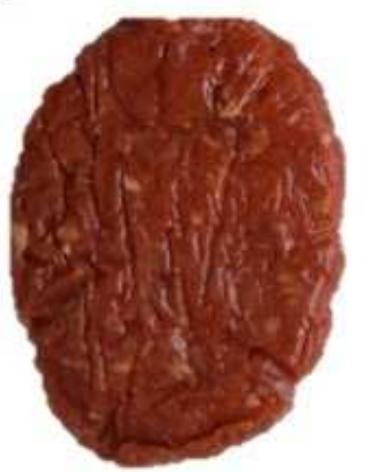

AST60

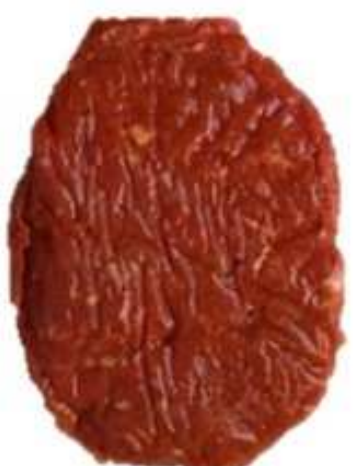

AST80

Fig. 1. Digital photographs of a recently-prepared lamb patty from each treatment: $\mathrm{CON}=$ control (no antioxidant additives); SULP $=450 \mathrm{mg}$ sodium metabisulphite per $\mathrm{kg}$ of patty mixture; $\mathrm{ASC}=500 \mathrm{mg}$ sodium ascorbate per $\mathrm{kg}$ of patty mixture; AST20 $=20 \mathrm{mg}$ of astaxanthin per $\mathrm{kg}$ of patty mixture; AST40 = $40 \mathrm{mg}$ of astaxanthin per $\mathrm{kg}$ of patty mixture; $\mathrm{AST} 60=60 \mathrm{mg}$ of astaxanthin per $\mathrm{kg}$ of patty mixture; AST80 $=80 \mathrm{mg}$ of astaxanthin per $\mathrm{kg}$ of patty mixture. 


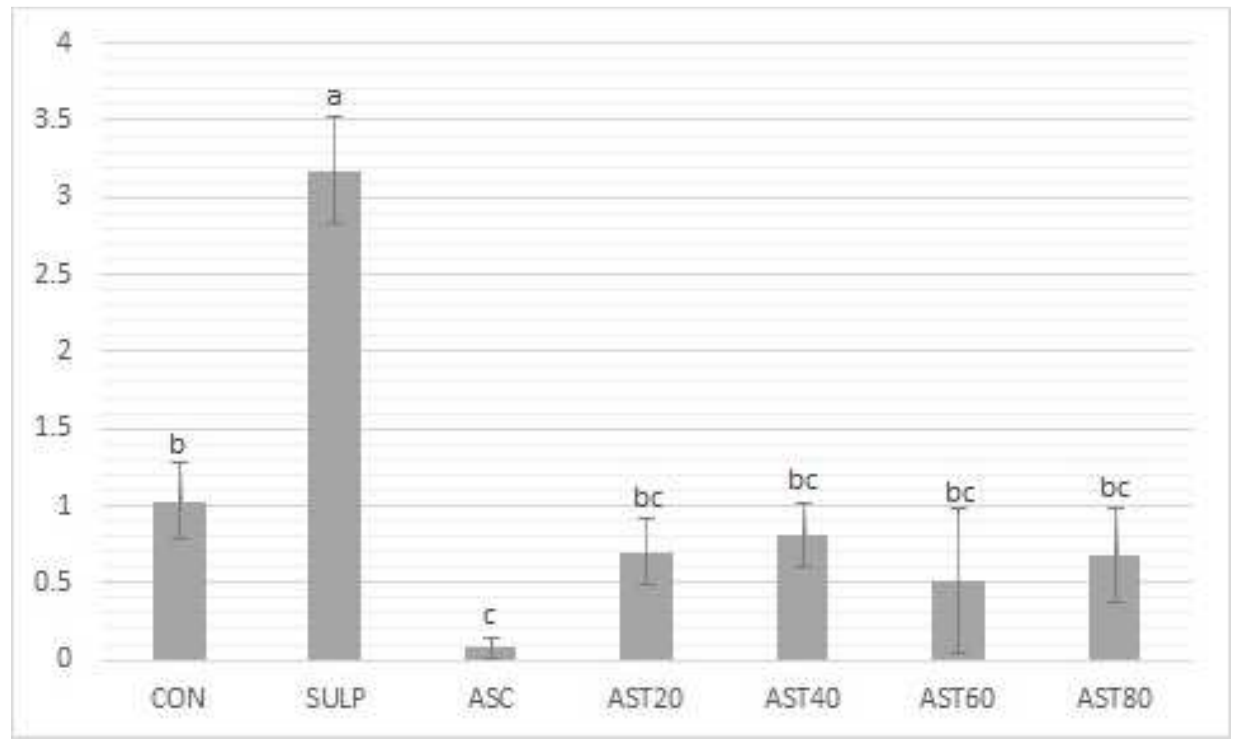

Fig. 2. Effect of different antioxidant treatments on the increment of the amount of thiobarbituric acid-reactive substances (TBARS; expressed as mg of malondialdehyde per $\mathrm{kg}$ of meat) in raw patties after a 3-month frozen storage at $-18{ }^{\circ} \mathrm{C}$ under aerobic packaging conditions. $\mathrm{CON}=$ control (no antioxidant additives); SULP $=450 \mathrm{mg}$ sodium metabisulphite per $\mathrm{kg}$ of patty mixture; $\mathrm{ASC}=500 \mathrm{mg}$ sodium ascorbate per $\mathrm{kg}$ of patty mixture; AST20 $=20 \mathrm{mg}$ of astaxanthin per $\mathrm{kg}$ of patty mixture; AST40 $=40 \mathrm{mg}$ of astaxanthin per $\mathrm{kg}$ of patty mixture; $\mathrm{AST} 60=60 \mathrm{mg}$ of astaxanthin per $\mathrm{kg}$ of patty mixture; AST80 $=80 \mathrm{mg}$ of astaxanthin per $\mathrm{kg}$ of patty mixture. Error bars represent standard deviation from the mean $(n=3)$. ${ }^{a b c}=$ different superscripts in the same row indicate statistical differences by the Tukey-Kramer test $(P<0.05)$. 